\title{
Ecology and Rubber-Growing
}

$\mathrm{B}^{\mathrm{R}}$ ROADLY speaking, there are two ways of 'growing' plants useful to man. The first and most obvious is to treat the plant as an agricultural crop, that is, to clear the ground of existing vegetation, prepare it by digging, ploughing, or other treatment, and then to sow or plant the crop, which is kept 'clean weeded'. The second is employed where large tracts of natural vegetation are useful as a whole, or contain useful species, as with pasture grasslands or forest. Here the primary attention required is to see that the regime of exploitation, by the grazing of stock or by felling, is not such as to impoverish the regetation as a whole, or to favour useless at the expense of useful species. Besides regulating the regime, active interference to these ends is sometimes required.

There are, of course, many crops which are managed by some intermediate method. Thus the primary crop may be sown or planted in the first instance, but other plants may be introduced or allowed to come naturally into the spaces between the crop plants because they are useful in assisting the growth of the main crop plant or in protecting the soil surface. A well-known example is the planting of 'nurse' trees or shrubs, which are eventually removed, between the seedlings or saplings of a young plantation. In all such cases we begin to approach the conditions of natural vegetation, in which more than one species grow in association and the different species present act and react onaone another, either favourably, or unfavour bly by direct competition for light, food or water. The study of such interactions under the given conditions of habitat is the most important part of what is called plant ecology.

The history of the great rubber-growing industry of the eastern tropics provides an interesting example of a change from the first towards the second of the two methods of treatment. When the first seedlings of Hevea brasiliensis were planted commercially in Malaya towards the end of last century, and for several years afterwards, when extremely remunerative results were being obtained, the universal practice, or at any rate the universal ideal, was to keep the plantation 'clean-weeded', and with the cheap labour obtainable this was quite possible on the more successful estates. But after a time it became increasingly clear that the practice was not everywhere desirable. Especially on sloping ground, the bare soil was exposed to erosion by the torrential rains and great damage was done: the soil also deteriorated by the direct action of sun and rain: it often became compact and hard, a result to which the constant trampling of the coolies contributed; and the absence of humus led to its impoverishment in essential mineral food stuffs. Consequently the trees began to suffer and their supply of latex to fall off. 'Clean weeding' began to lose its prestige; and this process was notably aided because, when the slump followed the boom, it was no longer so easy to find the necessary labour. 'Ground cover' began to be planted, at first leguminous plants, which, besides protecting the soil, were expected to increase its combined nitrogen. The legumes, however, were not very successful, largely because their growth under the rubber trees was unsatisfactory.

Then it occurred to someone to try the effect of allowing the natural 'weeds' of the forest to enter and colonise the plantations, which, of course, they had always been trying to do. The results were in many cases beneficial, and the practice became generally adopted. Now, in certain circles, the pendulum has swung to the other extreme, and it is even suggested that a rubber plantation should be treated like a self-regenerating natural forest, with its complex 'stories' of vegetation, and the rubber trees allowed to provide their own successors by sowing their own seed spontaneously! This extreme 'forestry method' of rubber cultivation is far from being generally supported. It is not, for example, the policy of the Rubber Research Institute, though the necessity of 'ground cover' in most cases is recognised. It is obviously true that much more experience is required before we can decide on the relative advantages of such a method of renewing plantations as compared with the established planting and 'budding'.

In a pamphlet recently published, Mr. Haines* gives, on the whole, a very fair and interesting review of the situation. He is in favour of what may be described as 'controlled natural ground cover'. Wild plants are allowed to come in, but discriminatingly, and when they become too luxuriant they are to be 'slashed' or otherwise kept down. Different species play different parts under different conditions, and it is impossible to lay down hard and fast rules that some of the natural colonists are 'good' and others 'bad'. All this is just what the ecologist would expect.

One remark of the author (p. 8) is very curious. "Practical planters are . . . advised to study competition as evidenced in the development in their fields, and to let Latin names and fine botanical distinctions take second place. Accurate

* Rubber Research Institute of Malaya. Planting Manual No. 6 : The Uses and Control of Natural Undergrowth on Rubber Estates. Research Institute of Malaya, 1934.) 1 dollar. 
naming of plants must always be helpful in assembling and disseminating information, but a very general classification on obvious features like the rate of growth, habit of growth, both above and below ground, texture of tissues and similar factors is quite adequate for the purpose in hand." But how on earth is a "practical planter", or anyone else, to "study competition" when he does not know the names of the competing species? Also how will a "very general classification" of the kind described help him here? It is obvious enough that it does not matter what language the names belong to-Latin, English or Malay(though the scientific names have well-known advantages), provided the same name is always used for the same species and for that species alone; but names in some language are quite indispensable. The planter must learn the names of the important species on his estate (or give them names of his own) before he can advance a single step in studying competition or increasing his knowledge in any way of what is going on in his plantations, once he lets in the native plants. Naturally, it is not necessary for him to acquire an exhaustive knowledge of the whole flora. When he has learned to distinguish the important species, then he can most usefully pay attention to their characters and behaviour under different conditions.

This, of course, is nothing but ecology, and we very much regret to see that, though Mr. Haines himself admits (p. 1) that "many of the problems which arise regarding natural covers are ecological", Mr. B. J. Eaton in his foreword summarises "the advantages of natural covers" solely in relation to their effect on soil, and writes that "for a study of this aspect of the problem the employment of a Forester or of a Plant Eeologist, as has been suggested in some quarters, is not essential". Well, the rubber industry may survive without such appointments, but that the whole problem is essentially ecological there can be no shadow of doubt. The soil problems as such, though an extremely important part of the whole, by no means exhaust the matter, as Mr. Haines is clearly aware, witness his constant stress on competition.

The general recognition of the fundamental importance of the ecological approach wherever we have to deal with communities of organisms living together is gradually coming, though it is distressingly slow. The ecologist is trained to consider the whole set of phenomena presented by such communities, and to discover which are of decisive and which of subordinate importance. Only when such knowledge has been acquired in any given case can the problem of rational treatment be successfully attacked. There are now young ecologists available-as there were not ten years ago-who have had this training, and it remains for the competent authorities to see that their services are employed in tackling the innumerable problems that await rational solution.

Specialists who have had a narrower training and very naturally think that 'there's nothing like leather', very often fail to come to grips with the larger aspects of their problems because they envisage them solely from one side. Ecologists can sometimes indicate the best solutions as soon as their survey of the field is completed, but very often experiment and specialised work are necessary after the general survey is completed. This is the proper sphere of the specialist, be he plant physiologist, mycologist, entomologist, pedologist or soil chemist. Ecologists have now been successfully engaged in the solution of the most various practical problems in New Zealand, in South Africa, in the United States, and elsewhere, but the fields ripe for their work are innumerable, and the proper management of the modern rubber plantation is clearly one of them.

A. G. T.

\section{Economy of Transport Overseas}

$\mathrm{M}^{\mathrm{B}}$ ERCANTILE vessels can be divided into three main classes-passenger ships, combined passenger and cargo ships and purely cargo ships. Of these it is the first class which receives the greatest attention in the public Press ; although the commerce of the world is carried on principally by tramps and freighters, these are seldom in the public eye. Generally speaking, unlike the steam locomotive, which was first used for mineral traffic before its potentialities for passenger traffic had been realised, the steam boat was regarded chiefly as a passenger carrying vessel.

The idea that steam vessels might prove of use for freight carrying, however, was not altogether absent from the minds of the pioneers, and a century and a half ago the oft-forgotten but deserving American inventor John Fitch wrote, "Here is an estimate which I beg leave to make. It takes thirty men to take a boat of thirty tons burthen from New Orleans to the Illinois. Now, I say, if I could be enabled to complete the experiment, I would obligate myself to make a boat of sixty tons burthen which, with engines and all complete, would cost $\$ 2,000$. As that could work double the time of the men at the oars, it could go half the time, and transport 120 tons in the same time that the other would thirty tons. At the rate now charged this would pay for 